\title{
Short-Term Variations of C18:1 Trans Fatty Acids in Plasma Lipoproteins and Ruminal Fermentation Parameters of Non-Lactating Cows Subjected to Ruminal Pulses of Oils
}

\author{
Einar Vargas-Bello-Pérez ${ }^{1,2, *} \mathbb{C}$, Juan J. Loor $^{3}(\mathbb{C})$ and Philip C. Garnsworthy ${ }^{2} \mathbb{C}$ \\ 1 Department of Veterinary and Animal Sciences, Faculty of Health and Medical Sciences, \\ University of Copenhagen, Grønnegårdsvej 3, DK-1870 Frederiksberg C, Denmark \\ 2 School of Biosciences, Sutton Bonington Campus, University of Nottingham, Loughborough LE12 5RD, UK; \\ Phil.Garnsworthy@nottingham.ac.uk \\ 3 Department of Animal Sciences and Division of Nutritional Sciences, University of Illinois, \\ 1207 West Gregory Drive, Urbana, IL 61801, USA; jloor@illinois.edu \\ * Correspondence: evargasb@sund.ku.dk
}

check for updates

Citation: Vargas-Bello-Pérez, E.; Loor, J.J.; Garnsworthy, P.C. Short-Term Variations of C18:1 Trans Fatty Acids in Plasma Lipoproteins and Ruminal Fermentation Parameters of Non-Lactating Cows Subjected to Ruminal Pulses of Oils. Animals 2021, 11, 788. https:// doi.org/10.3390/ani11030788

Academic Editor: Manuel Fondevila

Received: 17 February 2021

Accepted: 10 March 2021

Published: 12 March 2021

Publisher's Note: MDPI stays neutral with regard to jurisdictional claims in published maps and institutional affiliations.

Copyright: (C) 2021 by the authors Licensee MDPI, Basel, Switzerland. This article is an open access article distributed under the terms and conditions of the Creative Commons Attribution (CC BY) license (https:/ / creativecommons.org/licenses/by/ $4.0 /)$.
Simple Summary: The objective of this study was to evaluate short-term variations of trans fatty acids (TFA) in plasma lipoproteins and ruminal fermentation parameters of non-lactating cows subjected to ruminal pulses of vegetable oils. Over three-day periods, three non-lactating, nonpregnant Holstein cows received ruminal pulses of soybean oil, partially hydrogenated vegetable oil and a control with no added oil. In summary, results showed that for both oil treatments there was an accumulation of several C18:1 TFA in plasma and lipoproteins, especially on the third day of pulsing. Each C18:1 TFA responded differently to treatments over time.

Abstract: The objective of this study was to evaluate short-term variations of trans fatty acids (TFA) in plasma lipoproteins and ruminal fermentation parameters of non-lactating cows subjected to ruminal pulses of vegetable oils. Three non-lactating, non-pregnant Holstein cows, each with a ruminal cannula, were arranged in a $3 \times 3$ Latin square design with three-day pulsing periods and four-day washout intervals between treatments. Cows were treated with single ruminal pulses of: (1) control (skimmed milk (SM); $500 \mathrm{~mL}$ ); (2) soybean oil (SO; $250 \mathrm{~g} / \mathrm{d}$ in $500 \mathrm{~mL}$ of SM) and (3) partially-hydrogenated vegetable oil (PHVO; $250 \mathrm{~g} / \mathrm{d}$ in $500 \mathrm{~mL}$ of SM). Time changes after infusion in TFA contents were only observed for plasma C18:1 trans-4, trans-5 and trans- 12 , and high-density lipoprotein fraction C18:1 trans-9. After ruminal pulses, concentration of acetate decreased linearly; molar concentrations of propionate and valerate increased linearly; molar concentrations of butyrate and isovalerate changed quadratically and were greater at $1 \mathrm{~h}$ than at other times. There was an accumulation of several C18:1 TFA in plasma and lipoproteins, especially on the third day of pulsing. Overall, naturally occurring C18:1 TFA isomers (produced during ruminal biohydrogenation of SO) and preformed TFA (supplied by PHVO) elicited differential TFA partitioning and transport in plasma and lipoproteins.

Keywords: biohydrogenation; cows; lipoproteins; ruminal fluid; trans fatty acids; vaccenic acid

\section{Introduction}

Trans fatty acids (TFA) are produced naturally during biohydrogenation of polyunsaturated fatty acids (FA) in the rumen and are incorporated into milk fat [1]. The predominant TFA in ruminant fat is vaccenic acid (C18:1 trans-11), accounting for $60 \%$ to $80 \%$ of total TFA, although other TFA (e.g., C18:1 trans-10) occur when high-fat or high-concentrate diets are fed to ruminants. Partially hydrogenated vegetable oils (PHVO) contain a mixture of C18:1 trans isomers [2] and their proportions vary depending on the source of vegetable oil. In fact, PHVO from industrial origin contain up to 50\% TFA, mainly C18:1 trans-9 and 
C18:1 trans-10 [3]. Some TFA, such as C18:1 trans-11, have been reported to be beneficial for human health [4] and their concentrations can be increased in milk by high grass intakes [5], or by supplementing dairy cow diets with vegetable oils such as soybean [6], linseed, rapeseed and sunflower oils [7].

Cholesterol is important for plasma transport of FA in all mammals and plays vital roles in cell membrane structure and steroid hormone synthesis [8]. Although proportions of low- and high-density lipoproteins (LDL and HDL) have been studied extensively in humans, lipoproteins have received little attention in ruminants. The mammary gland appears to have differential uptake of lipids from lipoprotein fractions, which affects efficiency of transfer of long-chain fatty acids (LCFA; $>18$ carbon atoms) from diet to milk [9]. Sun and Gibbs [10] reported that FA profiles in ruminal digesta vary during the day, reflecting microbial colonization of newly ingested feed affecting the biohydrogenation pathways in grazing cattle. Loor et al. [11] suggested that ruminal $\mathrm{pH}$ changes and milk FA may be related, and Colman et al. [12] reported this with a logistic curve showing the link between those parameters. There are studies [13,14] reporting the effect of different dietary oils on FA transport in lipoprotein fractions of lactating and non-lactating cows. Those studies reported differences in the transport of FA in plasma lipoproteins over 21-day periods but did not evaluate short-term variations in C18:1 TFA in plasma lipoproteins. Evaluating short-term variations explains immediate responses to FA supply that provoke energy status changes, which are closely related to ruminal fermentation byproducts, such as production of propionic acid [15]. Also, dietary oils can result in extensive biohydrogenation effects that are often observed during the first few hours after administration [16].

From a productive perspective, feeding different sources of vegetable oils may be used to increase some TFA, such as C18:1 trans-11 in milk $[6,17,18]$, that are beneficial for human health, so it is important to understand time variations in C18:1 TFA that might arise from this approach. During the periparturient period, when cows are particularly susceptible to infection and inflammation, shifts in the composition of plasma lipids are coupled with changes in the FA composition of immune cells [19]. Compared with naturally occurring cis unsaturated FA, trans double bonds result in FA structurally analogous to saturated fats, leading to reduced cell membrane fluidity and possibly altered cell signaling. When included in the diet, therefore, TFA have the potential to integrate into cell membranes and alter immune cell function through various processes, including alteration in expression of genes encoding for pro-inflammatory mediators [20].

From a metabolic perspective, feeding non-lactating cows with different FA sources can be a strategy for priming lipid metabolism in dairy cows to cope with the metabolic challenges in the following early lactation phase [21]. In this regard, previous studies have fed dry cows with different FA sources focused on postpartum productive [21-23] and reproductive traits [24,25]; however, no report is available on dry cows' short-term metabolism of TFA.

Identifying times when lipid supplements are less affected by ruminal biohydrogenation or have less effect on ruminal fermentation parameters (e.g., $\mathrm{pH}, \mathrm{NH}_{3}-\mathrm{N}$ and volatile fatty acids) is valuable information for ruminant nutritionists. In this regard, studies in which oils are ruminally infused as pulses are limited. Due to the aforementioned background, before performing large, controlled feeding trials and on-farm experiments in lactating animals, the approach of this study was to analyze the short-term effects of different FA sources on blood lipoproteins and rumen fermentation parameters in nonlactating dairy cows. Another feature of our approach was to consider how C18:1 TFA are partitioned and transported into lipoproteins. Therefore, the objective of this study was to evaluate the short-term variations of C18:1 TFA in plasma lipoproteins and ruminal fermentation parameters of cows subjected to ruminal pulses of vegetable oils. 


\section{Materials and Methods}

\subsection{Animals and Treatments}

All procedures were reviewed by the Animal Welfare and Ethical Review Board of the University of Nottingham and were conducted in accordance with the requirements of the UK Home Office Animals (Scientific Procedures) Act 1986 under project licence ID 40/2751. Three non-lactating, non-pregnant Holstein multiparous cows (BW $=773 \pm 63 \mathrm{~kg}$ (average $\pm S D$ )), each with a ruminal cannula, were utilized in a $3 \times 3$ Latin square design with a three-day treatment period followed by a four-day washout interval between treatments to minimize carryover effects. The periods were short because the effect of FA and energy absorption were assumed to regulate ruminal fermentation parameters in the short-term [15].

The basal diet consisted of meadow hay (ad libitum; approximately $8 \mathrm{~kg} / \mathrm{d}$ ) and a commercial concentrate (2 kg/day). Meadow hay contained 87\% dry matter (DM), 9.3\% DM crude protein, $63 \%$ DM neutral detergent fiber, $38 \%$ DM acid detergent fiber and $1.6 \% \mathrm{DM}$ ether extract, as determined in a commercial feed laboratory. The basal diet was formulated to meet $110 \%$ of nutrient requirements for maintenance of a non-lactating, non-pregnant cow weighing $750 \mathrm{~kg}$ [26]. Ingredients and chemical composition of the commercial concentrate are shown in Table 1 . The animals had ad libitum access to hay, and the commercial concentrate was offered at 12:00 ( $3 \mathrm{~h}$ after the pulse of lipids). Cows were dosed at 09:00 with ruminal pulses of: (1) control (skim milk (SM); $500 \mathrm{~mL} / \mathrm{d}$ ); (2) soybean oil (SO; $250 \mathrm{~g} / \mathrm{d}$ in $500 \mathrm{~mL} / \mathrm{d}$ of SM) and (3) partially hydrogenated vegetable oil (PHVO; $250 \mathrm{~g} / \mathrm{d}$ in $500 \mathrm{~mL} / \mathrm{d}$ of SM). PHVO was supplied by Aarhus Karlshamn Ltd. (Hull, UK) and was based on hydrogenated rapeseed oil. Quantities of fat and SM in ruminal pulses were calculated according to previous studies [27]. The control supplied $3 \%$ (of total diet DM) of ether extract while SO and PHVO supplied 4\% (of total diet DM) of ether extract.

Table 1. Ingredients and declared chemical composition of the concentrate.

\begin{tabular}{cc}
\hline & Concentrate $^{\mathbf{1}}$ \\
\hline Ingredient composition (\% of dry matter) & 50 \\
Rolled barley & 15 \\
Sugar beet pulp & 15 \\
Rolled wheat & 5 \\
Cane molasses & 5 \\
Limestone flour & 5 \\
Vitamins & 5 \\
Minerals & \\
Chemical composition (\% of dry matter) & 8 \\
Neutral detergent fiber & 14 \\
Crude protein & 3 \\
Ether extract & 7 \\
Ash &
\end{tabular}

${ }^{1}$ Commercial concentrate from Manor Farm Feeds, Oakham, UK.

During pulses and sampling periods, cows were housed in tie-stalls and had free access to water. Treatment oil emulsions were delivered through the rumen cannula as ruminal pulses once daily at 09:00 over three days. Emulsions were prepared the day before each pulse. To provide a homogenized release of pulses, skim milk was used $(500 \mathrm{~mL} / \mathrm{d})$ to emulsify the oils (SO and PHVO) using a laboratory mixer emulsifier (L2R Silverson, Machines Ltd., Waterside, Chesham, UK). Before each pulse, emulsions were heated for $30 \mathrm{~min}$ at $30^{\circ} \mathrm{C}$ in a water bath (Grant Y28, Cambridge Ltd., Cambridge, UK) to provide easier diffusion of PHVO. The FA profile of treatment oils and emulsions is shown in Table 2. 
Table 2. Fatty acid composition of oils, skimmed milk and emulsions used for ruminal pulses.

\begin{tabular}{|c|c|c|c|c|c|}
\hline \multicolumn{3}{|c|}{ Oils } & \multicolumn{3}{|c|}{ Treatment Emulsions ${ }^{4}$} \\
\hline Fatty Acid, g/100 g & SO $^{1}$ & $\mathrm{PHVO}^{2}$ & Control $^{3}$ & $\mathrm{SO}+\mathrm{SM}$ & PHVO + SM \\
\hline C10:0 & - & - & 2.51 & - & - \\
\hline C12:0 & - & 0.23 & 2.14 & - & 0.24 \\
\hline C14:0 & 0.07 & 0.18 & 7.89 & 0.08 & 0.30 \\
\hline C14:1 & - & - & 0.50 & - & - \\
\hline C15:0 & - & - & 0.98 & - & - \\
\hline C16:0 & 10.74 & 7.82 & 27.02 & 10.84 & 7.80 \\
\hline C16:1 & - & - & 1.54 & - & 0.13 \\
\hline C17:0 & - & - & 0.63 & 0.08 & 0.07 \\
\hline C18:0 & 4.28 & 8.35 & 11.69 & 4.30 & 8.15 \\
\hline C18:1 trans -4 & - & 0.59 & - & - & 0.48 \\
\hline C18:1 trans -5 & - & 1.48 & - & - & 1.38 \\
\hline C18:1 trans- $6-8$ & - & 8.39 & - & - & 8.33 \\
\hline C18:1 trans-9 & - & 17.60 & - & - & 16.67 \\
\hline C18:1 trans-10 & - & 9.28 & - & - & 8.96 \\
\hline C18:1 trans-11 & - & 7.67 & 1.70 & - & 7.54 \\
\hline C18:1 trans-12 & - & 7.35 & - & - & 6.97 \\
\hline C18:1 cis-9 & 22.42 & 6.06 & 21.08 & 22.33 & 6.27 \\
\hline $\begin{array}{l}\text { C18:2 trans }-9, \\
\text { cis- } 12\end{array}$ & - & 1.13 & - & - & 0.84 \\
\hline C18:2 cis-9, cis-12 & 53.03 & 0.42 & 3.39 & 52.90 & 0.46 \\
\hline C20:0 & 0.34 & 0.76 & - & 0.34 & 0.73 \\
\hline C18:3 cis-6, 9, 12 & - & 0.42 & - & - & 0.58 \\
\hline C20:1 & 0.20 & - & - & 0.18 & 0.15 \\
\hline C18:3 cis- $9,12,15$ & 6.78 & 0.06 & 0.61 & 6.75 & 0.14 \\
\hline C18:2 cis-9, trans-11 & - & - & 1.03 & - & - \\
\hline C20:2 & 0.05 & 0.05 & - & - & - \\
\hline C22:0 & 0.38 & 0.44 & - & 0.37 & 0.42 \\
\hline C24:0 & 0.15 & 0.15 & - & 0.14 & 0.18 \\
\hline Other ${ }^{5}$ & 1.56 & 21.57 & 17.29 & 1.69 & 23.21 \\
\hline
\end{tabular}

${ }^{1} \mathrm{SO}=$ soybean oil $;{ }^{2} \mathrm{PHVO}=$ partially hydrogenated vegetable oil $;{ }^{3} \mathrm{SM}=$ skim milk; ${ }^{4}$ single administration per day, ${ }^{5}$ fatty acids $<0.03 \mathrm{~g} / 100 \mathrm{~g}$.

\subsection{Ruminal Fluid Samples}

Samples of ruminal fluid $(50 \mathrm{~mL})$ were collected from various parts (around $17 \mathrm{~mL}$ per site) of the rumen (anterior, dorsal and mid-ventral regions) using a syringe screwed to a stainless tube. Ruminal fluid samples were collected prior to ruminal pulse $(0 \mathrm{~h}$; 09:00) and at 1 (10:00), $3 \mathrm{~h}$ (12:00) and $6 \mathrm{~h}$ (15:00) post pulsing during the $3 \mathrm{~d}$ collection periods. Immediately after fluid collection, a $10 \mathrm{~mL}$ aliquot of ruminal fluid was used to determine $\mathrm{pH}$ by using a pH meter (Piccolo Plus, HI 1295, Hanna Instruments, Póvoa de Varzim, Portugal). Following pH determination (recorded at 0, 1, 2, 3 and 6 h), ruminal fluid was centrifuged at $20^{\circ} \mathrm{C}$ for $10 \mathrm{~min}$ at $3000 \times \mathrm{g}$ (Centaur $2 \mathrm{MSE}$, Milton Keynes, UK). Immediately after rumen fluid collection, a $10 \mathrm{~mL}$ aliquot of ruminal fluid supernatant was preserved by adding $1 \mathrm{~mL}$ of $25 \%$ metaphosphoric acid for volatile fatty acid (VFA) determination, and another $10 \mathrm{~mL}$ aliquot of untreated ruminal fluid was kept for $\mathrm{NH}_{3}-\mathrm{N}$ analysis. Analyses of VFA and $\mathrm{NH}_{3}-\mathrm{N}$ were only done at $0,1,2$ and $3 \mathrm{~h}$. Samples were immediately frozen at $-20{ }^{\circ} \mathrm{C}$ for later analysis.

Samples of ruminal fluid were analyzed for VFA using a gas chromatograph (GC; Agilent, GC 6890 series, Stockport, UK) equipped with a CP-Sil 88 fused-silica capillary column $(100 \mathrm{~m} \times 0.25 \mathrm{~mm}$ i.d., with $0.2-\mu \mathrm{m}$ film thickness; Varian Inc., Oxford, UK). A flame ionization detector was used with an oven initial temperature of $140{ }^{\circ} \mathrm{C}$ and maximum temperature of $250{ }^{\circ} \mathrm{C}$ and an equilibrium time of $0.50 \mathrm{~min}$. The inlet temperature was $300{ }^{\circ} \mathrm{C}$, the split ratio was $15: 1$ and a $1-\mu \mathrm{L}$ injection volume was used. The detector temperature was $250{ }^{\circ} \mathrm{C}$, hydrogen carrier gas flow to the detector was $40.0 \mathrm{~mL} / \mathrm{min}$, airflow was $450 \mathrm{~mL} / \mathrm{min}$ and the flow of nitrogen makeup gas was $45.0 \mathrm{~mL} / \mathrm{min}$. A 
volatile free acid mixture standard (Supelco-46975-U; Sigma-Aldrich, Gillingham, UK) was used for VFA determination. Ruminal $\mathrm{NH}_{3}-\mathrm{N}$ was determined by a photometric test with a Clinical Chemistry Auto Analyzer using an enzymatic ultraviolet method (Rx Imola; Randox Laboratories Ltd., Cat. No. AM3979, Crumlin, UK).

\subsection{Plasma Samples}

Blood samples $(10 \mathrm{~mL})$ were obtained via jugular catheter (placed the day before sampling periods) prior to the pulse $(0 \mathrm{~h})$ and at 1, 2, 3 and $6 \mathrm{~h}$ after pulsing during each three-day collection period for lipoprotein fractionation. Immediately after sampling, blood was transferred to EDTA tubes and centrifuged at $20{ }^{\circ} \mathrm{C}$ for $10 \mathrm{~min}$ at $3000 \times g$ (Centaur 2 MSE, Milton Keynes, UK) for harvesting plasma. Based on their density, lipoprotein fractions were separated sequentially by preparative ultracentrifugation in a Beckman XL-70 preparative centrifuge (Beckman Coulter UK Ltd., High Wycombe, UK). Potassium bromide was added to the plasma to obtain the required density calculated by use of the Radding and Steinberg [28] formula. Plasma was separated into lipoprotein fractions (LDL and HDL fractions) by ultracentrifugation at $39,000 \times g$ for $20 \mathrm{~h}$ at $12{ }^{\circ} \mathrm{C}$. Tubes were carefully removed after ultracentrifugation and each tube was cut using a Kontron bench tube slicer to retrieve the top layer, which was predominantly a LDL fraction. The density of lipoprotein and $\mathrm{KBr}$ solution was re-adjusted to obtain the HDL fraction and tubes were ultracentrifuged at $39,000 \times g$ for $40 \mathrm{~h}$ at $12{ }^{\circ} \mathrm{C}$. Tubes were carefully removed from the centrifuge and cut as previously described.

\subsection{Fatty Acid Analysis}

Lipids from plasma and lipoprotein fractions were extracted according to Hara and Radin [29] by using hexane:isopropanol (3:2) and sodium sulfate; then transmethylated with $0.5 \mathrm{M}$ sodium methoxide/methanol following chemical derivatization with $50 \% \mathrm{BF}$ $\mathrm{MeOH}$. All chemicals and solvents used for this method were of analytical grade. For analysis of FA in plasma and lipoprotein fractions, a GC system (Agilent, GC 6890 series, Stockport, UK) equipped with a CP-Sil 88 fused-silica capillary column $(100 \mathrm{~m} \times 0.25 \mathrm{~mm}$ i.d., with $0.2 \mu \mathrm{m}$ film thickness; Varian Inc., Oxford, UK) was used. The GC conditions were as follows: the oven temperature was initially set at $110{ }^{\circ} \mathrm{C}$ for $4 \mathrm{~min}$ after injection and then increased to $240{ }^{\circ} \mathrm{C}$ with equilibration time of $2 \mathrm{~min}$. The inlet and flame-ionization detector temperatures were $260^{\circ} \mathrm{C}$, the split ratio was $15: 1$ and a $2-\mu \mathrm{L}$ injection volume was used. The hydrogen carrier gas flow to the detector was $25 \mathrm{~mL} / \mathrm{min}$, airflow was $400 \mathrm{~mL} / \mathrm{min}$, and the flow of nitrogen makeup gas was $40 \mathrm{~mL} / \mathrm{min}$. Fatty acid peaks were identified by using a fatty acid methyl ester standard (FAME; Supelco 37 Component FAME mix, Bellefonte, PA, USA) and a TFA reference standard (C18:1 trans-11, methyl ester, Supelco, Bellefonte, PA, USA).

\subsection{Statistical Analysis}

Animals were arranged in a $3 \times 3$ Latin square design and data were analyzed as repeated measurements across time using the Genstat statistical package (19th Edition; VSN International Ltd., Oxford, UK) with the following model:

$$
Y_{i j k l}=\mu+T_{i}+P_{j}+C_{k}+S_{l}+D_{t}+T_{i} \times S_{1}+T_{i} \times D_{t}+e_{i j k l}
$$

where $Y_{i j k l}$ is the observation, $\mu$ is the population mean, $T_{i}$ is the treatment $(i=$ control, SO or PHVO), $P_{j}$ is the period $(j=1,2$ or 3$), C_{k}$ is the random effect of cow $(k=1,2$ or 3), $S_{1}$ is the sampling day within the period $(1=1,2$ or 3$), D_{t}$ is the sampling time within day $(1,2,3,4$ or $6 \mathrm{~h}), T_{i} \times S_{1}$ is the treatment $\times$ sampling day interaction, $T_{i} \times D_{t}$ is the treatment $\times$ sampling time interaction and $e_{i j k l}$ is the residual error, which includes all other interactions, none of which were significant. Tukey's test was used to identify significant differences between means. Probability of $p<0.05$ was used to declare significant differences among means. Results are reported as least-square means for effects of interest, with observations pooled to ensure appropriate error terms for each comparison. Thus, 
day means are for pooled times, time means are for pooled days, and $n=3$ for each individual mean.

\section{Results and Discussion}

\subsection{Fatty Acid Profile of Oils and Emulsions}

The most abundant FA in dietary oils were the following: SO contained ( $\mathrm{g} / 100 \mathrm{~g}$ of total FA) 22 of C18:1 cis-9 and 53 of C18:2 cis-9, 12 (no C18:1 TFA were detected in this oil); PHVO contained (g/100 g of total FA) 8 of C16:0 and 8 of C18:0. The PHVO also contained (g/100 g of total FA) some C18:1 TFA: 0.59 of C18:1 trans-4, 1.48 of C18:1 trans-5, 18 of C18:1 trans-6-8, 8 of C18:1 trans-9, 9 of C18:1 trans-10, 8 of C18:1 trans-11 and 7 of C18:1 trans-12. The SO emulsion contained a high proportion of polyunsaturated FA, mainly C18:2 cis-9, cis-12 ( 50 g/100 g) and C18:1 cis-9 ( 20 g/100 g). The PHVO emulsion contained a high proportion $(\sim 50 \mathrm{~g} / 100 \mathrm{~g})$ of TFA covering the range of C18:1 trans positional isomers from trans-4 to trans-12. C18:1 trans isomers were not detected in the SO emulsion while control only presented C18:1 trans-11.

\subsection{Ruminal Fermentation Parameters}

There was no treatment by period interaction in any of the fermentation parameters. Ruminal $\mathrm{NH}_{3}-\mathrm{N}$ concentration $(\mathrm{mmol} / \mathrm{L})$ was higher $(p<0.05)$ for control (15) and PHVO (13) than for SO (8). Total VFA concentration (mmol/L) in ruminal fluid was lower $(p<0.05)$ for PHVO (72), and SO (72) than control (90). Ruminal pH and molar percentages of acetate, propionate, butyrate, isobutyrate, valerate and isovalerate were not affected $(p>0.05)$ by treatments. Dietary lipids can reduce fiber digestibility and alter ruminal fermentation parameters [27]. Ruminal pulses of SO and PHVO decreased $(p<0.05)$ total ruminal VFA concentration; this effect may be related to a reduced availability of rapidly fermentable carbohydrate in the rumen [30] or a decrease in fiber digestion [31].

Ruminal pulses of SO decreased $(p<0.05) \mathrm{NH}_{3}-\mathrm{N}$ concentration. It is possible that $\mathrm{SO}$ reduced availability of fermentable carbohydrates for microbial synthesis [32]. Availability of fermentable carbohydrates would be reduced if SO physically coated dietary fiber and concentrates, thus making them inaccessible to microbial attack. Less physical coating would be expected with PHVO due to its higher melting point compared with SO. Introduction of one cis double bond into a FA chain reduces melting point considerably compared to saturated FA chains with the same number of carbon atoms [33]. In a previous experiment where cows were supplemented with 3\% (DM basis) of SO or PHVO, Vargas-Bello-Pérez et al. [34] reported no effect on $\mathrm{NH}_{3}-\mathrm{N}$ and total concentration of VFA.

Effects of dietary oil supplementation on ruminal $\mathrm{NH}_{3}-\mathrm{N}$ concentration can be variable and other factors are related to $\mathrm{NH}_{3}-\mathrm{N}$ production: protozoa counts and contents of proteolytic bacteria [35]. In a meta-analysis, it was reported that rumen protozoa decrease when ruminants are fed with lipid supplements and that this is due to changes in membrane permeability [36]. Conversely, protozoa membranes are more susceptible to the action of medium-chain FA such as palmitic acid [37], which was present in both oils used in this study. Thus, in the present study, concentration of $\mathrm{NH}_{3}-\mathrm{N}$ may have decreased due to exclusion of protozoal proteolytic and deamination enzymes [38].

Ruminal $\mathrm{pH}$ and $\mathrm{NH}_{3}-\mathrm{N}$ did not differ $(p>0.05)$ between days. Ruminal $\mathrm{pH}$ decreased linearly $(p<0.05)$ from 6.62 to 6.27 and was lower at $6 \mathrm{~h}$ post-rumen pulsing than at other times. This agrees with the decrease of ruminal $\mathrm{pH}$ (from 6.30 to 5.70) reported by Gustafsson and Palmquist [39] when cows (fed corn silage, alfalfa hay and concentrate) were sampled throughout $16 \mathrm{~h}$ post-feeding. Sun and Gibbs [10] reported the lowest rumen $\mathrm{pH}$ value (6.07) at night (from 18:00 to 6:00). Under the conditions of our study, the drop in rumen $\mathrm{pH}$ (lowest at $6 \mathrm{~h}$ post-rumen pulse) could be related to concentrate feeding rather than the lipid pulses.

Ruminal $\mathrm{NH}_{3}-\mathrm{N}$ increased quadratically $(p<0.05)$ from 11 to $17 \mathrm{mmol} / \mathrm{L}$ and was greater $(p<0.05)$ at $3 \mathrm{~h}$ post-rumen pulsing than at other times. Total VFA were not affected $(p>0.05)$ by day or time of sampling. Concentrations of acetate, propionate, 
butyrate, valerate and isovalerate did not differ between days. Concentration of acetate decreased linearly $(p<0.05)$; molar concentration of propionate and valerate increased linearly $(p<0.05)$; and molar concentrations of butyrate and isovalerate decreased quadratically $(p<0.05)$ and were greater $(p<0.05)$ at $1 \mathrm{~h}$ post-rumen pulsing than at other times, but molar concentration of valerate was not affected by time of sampling (Figure 1). As reported by Gustafsson and Palmquist [39], in the current study concentrations of propionate and butyrate increased, whereas acetate decreased after the first hours post daily morning feeding.
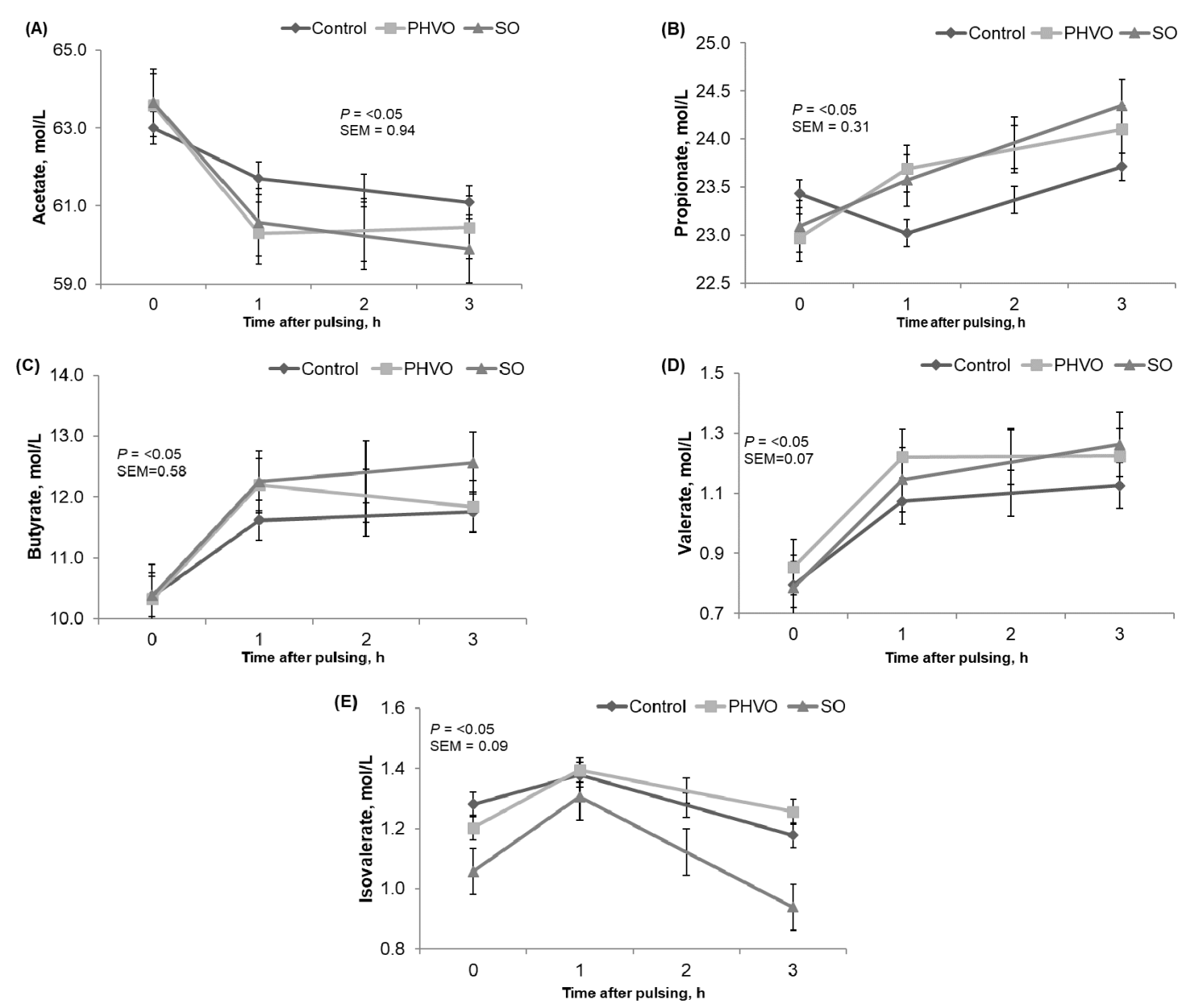

Figure 1. Time variations of volatile fatty acids from cows subjected to ruminal pulses of control, partially hydrogenated vegetable oil (PHVO) and soybean oil (SO). (A) Acetate; (B) propionate; (C) butyrate; (D) valerate and (E) isovalerate. Ruminal fluid samples were collected prior to ruminal pulse $(0 \mathrm{~h} ; 09: 00)$ and at 1 and $3 \mathrm{~h}$ after ruminal pulse (10:00 and 12:00). SEM = standard error of the mean. Probability of $p<0.05$ was used to determine significant differences between means. Means are pooled across days for each cow. $p$-value represents the effect of sampling time.

\subsection{Treatment Effects on Plasma and Lipoprotein Fractions}

There was no treatment by period interaction for any FA in plasma and lipoproteins. Compared with control and SO, PHVO increased $(p<0.05)$ plasma concentrations $(\mathrm{g} / 100 \mathrm{~g}$ of total FA) of C18:1 trans-4 (0.001 and 0.001 vs. 0.2$)$ and C18:1 trans-5 ( 0.1 and 0.1 vs. $0.2)$. However, $\mathrm{C} 18: 1$ trans-12 was higher $(p<0.05)$ in SO and PHVO than control $(0.3$ vs. 0.3 and 0.2). As expected, we detected higher concentrations of C18:1 trans isomers in PHVO pulses.

Concentrations $(\mathrm{mg} / \mathrm{L})$ of HDL and LDL fractions were not affected by treatment $(p>0.05)(0.4 \pm 0.05 \mathrm{mg} / \mathrm{L}$ for HDL and $0.1 \pm 0.002 \mathrm{mg} / \mathrm{L}$ for LDL). Compared with control, SO and PHVO increased $(p<0.05)$ HDL content of C18:1 trans-9 $(0.01$ and 0.02 
vs. $0.09 \mathrm{~g} / 100 \mathrm{~g}$ of total FA). This TFA has been reported as one of the most predominant C18:1 trans isomers in PHVO [2]. Compared with control and PHVO, SO resulted in higher $(p<0.05)$ concentrations of C18:1 trans-11 ( 0.5 and 0.5 vs. 0.7$)$ in the LDL fraction. Compared with control and SO, PHVO resulted in higher $(p<0.05)$ concentrations $(\mathrm{g} / 100 \mathrm{~g}$ of total FAs) of C18:1 trans-5 (0.04 and 0.09 vs. 0.2), C18:1 trans-9 (0.09 and 0.2 vs. 0.5$)$, and C18:1 trans -10 (0.08 and 0.1 vs. 0.5$)$ in the LDL. Compared with control and PHVO, SO resulted in higher $(p<0.05)$ concentrations of C18:1 trans-11 (1.1 and 1.3 vs. 2.6) in the LDL fraction. The increased contents of C18:1 trans -11 in both HDL and LDL fractions by SO are in agreement with previous studies $[13,34]$. This is because unsaturated FA sources such as SO lead to formation and accumulation of C18:1 trans-11 in the rumen [40].

In general, PHVO increased most C18:1 trans isomers in the LDL fraction, some of which have been negatively correlated with milk fat synthesis (i.e., C18:1 trans-10 and C18:2 trans-10, cis-12). In this regard, our gas chromatography protocol was able to detect C18:1 trans-10. This TFA deserves special attention since it is related to milk fat depression in lactating ruminants [41] and can affect expression of several genes involved in lipid metabolism in the mammary gland [42]. This study agrees with previous reports where the LDL fraction appears to be the main lipoprotein transporting C18:1 trans isomers and is more responsive than other lipoprotein fractions to variation in supply of dietary lipids [14].

\subsection{Plasma and Lipoproteins: Day and Time Changes}

Except for C18:1 trans-11, plasma concentrations of all C18:1 trans isomers increased linearly $(p<0.05)$ with day of treatment, and were higher $(p<0.05)$ on day 3 than on days 1 and 2 (Figure 2). C18:1 trans-11 was not increased in plasma but it showed a linear increased across sampling days. This trans isomer is crucial for formation of C18:2 cis-9, trans-11, and for dairy consumers this FA is important because it has potential benefits for human health [4]. Plasma concentrations of C18:1 trans- 4 and C18:1 trans-12 were greater $(p<0.05)$ at $1 \mathrm{~h}$ post-rumen pulsing than at other times; concentrations of C18:1 trans-5 were greater $(p<0.05)$ at $2 \mathrm{~h}$ and $6 \mathrm{~h}$ post-rumen pulsing than at other times; concentrations of the remaining C18:1 trans isomers were not affected $(p>0.05)$ by time of sampling (Figure 3).

Concentrations of C18:1 trans-9, trans-11 and trans-12 in the HDL fraction increased linearly $(p<0.05)$ with day of treatment and were higher $(p<0.05)$ on day 3 than on days 1 and 2 (Figure 2). Concentrations of C18:1 trans-4 in the HDL fraction changed quadratically $(p<0.05)$; concentrations of C18:1 trans-9 were greater $(p<0.05)$ at $3 \mathrm{~h}$ and $6 \mathrm{~h}$ post-rumen pulsing than at other times; concentrations of the remaining C18:1 trans isomers were not affected $(p>0.05)$ by time of sampling (Figure 4$)$.

There was a linear effect $(p<0.05)$ of the day on C18:1 trans-9, trans-10, trans-11 and trans-12 in the LDL fraction. These concentrations were higher $(p<0.05)$ on day 3 than on days 1 and 2, but concentrations of C18:1 trans- 4 and trans -5 in the LDL fraction did not differ $(p>0.05)$ between days (Figure 2). Concentrations of C18:1 trans isomers in the LDL fraction were not affected $(p>0.05)$ by time of sampling. Sun and Gibbs [10] reported diurnal variation in concentration of C18:1 trans-11 in rumen digesta of grazing cows, with higher concentrations early in the morning from 02:00 to 06:00 h. In the current study, however, there was no time effect on concentration of C18:1 trans-11 in plasma and lipoprotein fractions. As rumen concentration and rumen production/uptake of C18:1 trans-11 are not always related, and rumen volume varies considerably in grass-fed cows, a consistent C18:1 trans-11 supply to the plasma is not precluded by having a rumen concentration flux across the day. C18:1 trans- 11 can be converted to C18:2 cis-9, trans11 (rumenic acid) through the action of stearoyl coenzyme A desaturase and it has been estimated that $20 \%$ of C18:1 trans-11 can be converted to C18:2 cis-9, trans-11 in humans [43]. Rumenic acid has been identified as anti-carcinogenic, anti-atherosclerotic, antioxidative and an immunomodulator [44]. The current study shows that C18:1 trans-11 did not vary across time after pulsing, but this isomer increased with days of treatment with both 
treatments. Thus, under the conditions of the current study, it may be advised to feed lactating cows with $\mathrm{SO}$ rather than $\mathrm{PHVO}$, since PHVO can increase contents of other isomers such as C18:1 trans-10, which may reduce milk fat yield.

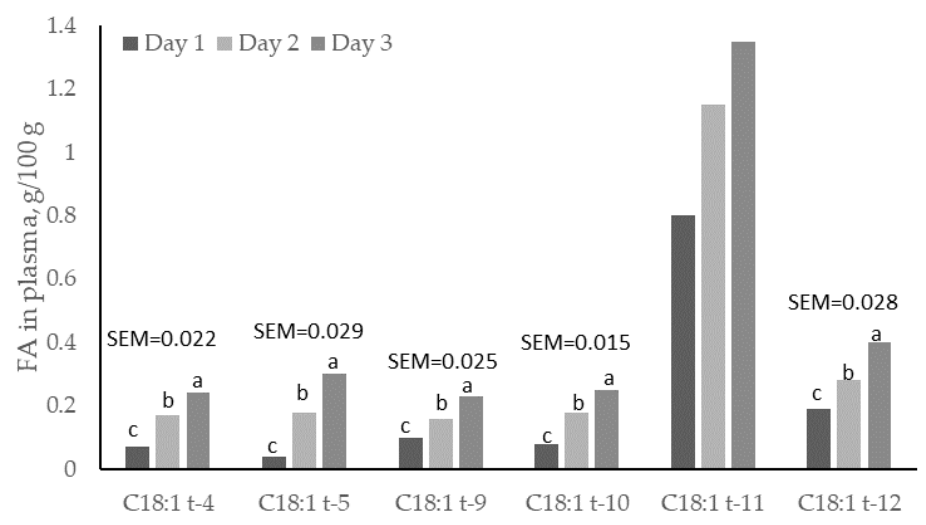

(A)

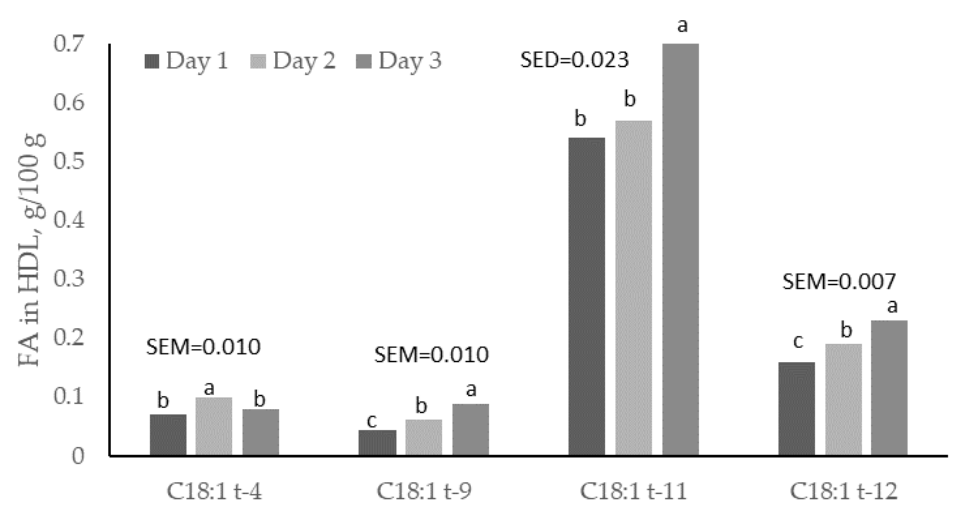

(B)

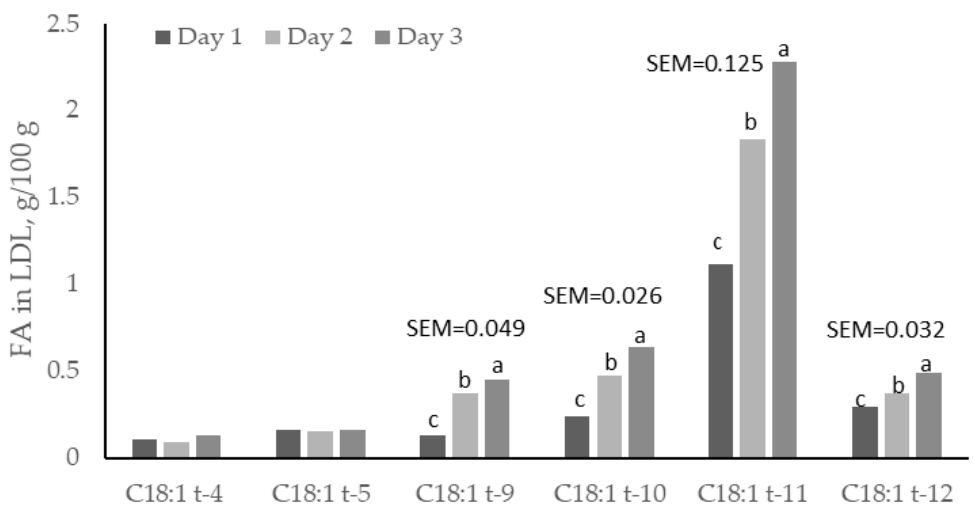

(C)

Figure 2. Day variations of C18:1 trans fatty acids (FAs) in (A) total plasma; (B) high-density lipoprotein (HDL) and (C) low-density lipoprotein (LDL) fractions from cows subjected to ruminal pulses of control, partially hydrogenated vegetable oil and soybean oil. SEM = standard error of the mean. ${ }^{a, b, c}$ Means with different superscripts differ significantly $(p<0.05)$. Pooled means of control, partially hydrogenated vegetable oil and soybean oil per day are shown. $p$-value represents the effect of sampling day.

Although ruminal microbial activity was not measured in the current study, blood FA profiles were used as an indirect approach to visualize how infused FA were affected 
during rumen biohydrogenation [45]. Rumen pulses do not bypass biohydrogenation; hence, FA supply to the duodenum should be similar to supplies observed when oilseeds or oils are included in the diet. Rumen pulses are more representative of FA normally available to the animal than duodenal infusions. In the current study, however, a discrete lipid infusion (as opposed to lipids mixed with total mixed rations) may have provoked shifts in rumen motility and postprandial outflow, which may have influenced escape of rumen biohydrogenation products to the blood circulation. Post-ruminal infusions can be used to test hypotheses about intestinal uptake, but they only mimic rumen-protected lipids [46]. In on-farm conditions, there is a minimal loss of FA from the rumen by absorption either across the ruminal epithelium or by catabolism to VFA or $\mathrm{CO}_{2}$ [47]. In addition, microbes synthesize FA de novo from carbohydrate precursors. Therefore, lipids reaching the duodenum consist of FA from both dietary (around $87 \%$ coming from feed; [48]) and microbial origins [49].

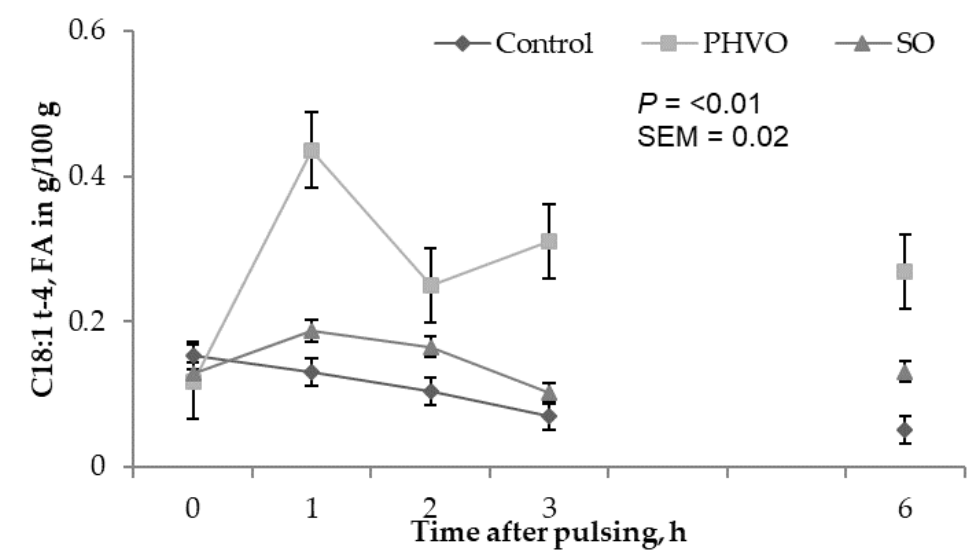

(A)

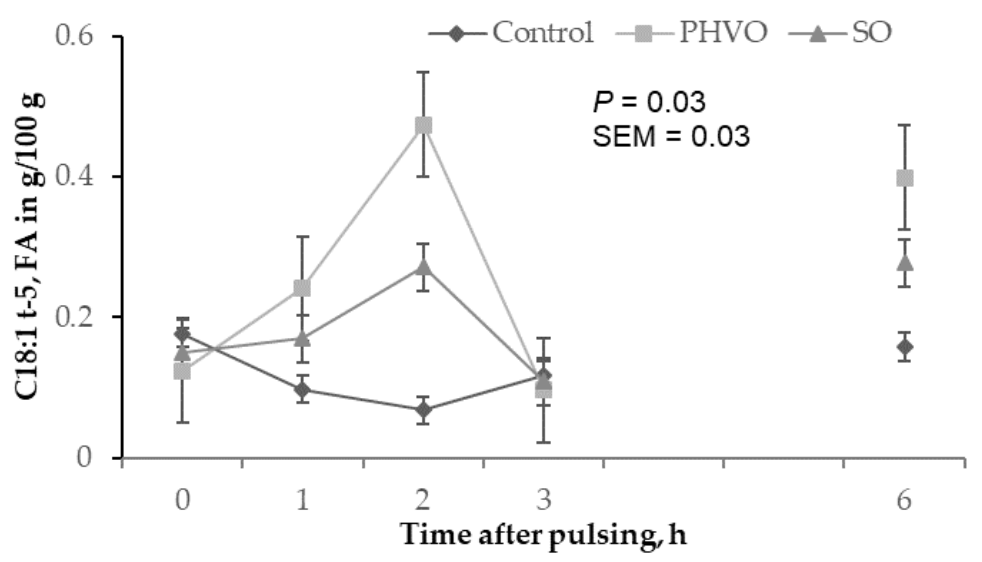

(B)

Figure 3. Cont. 


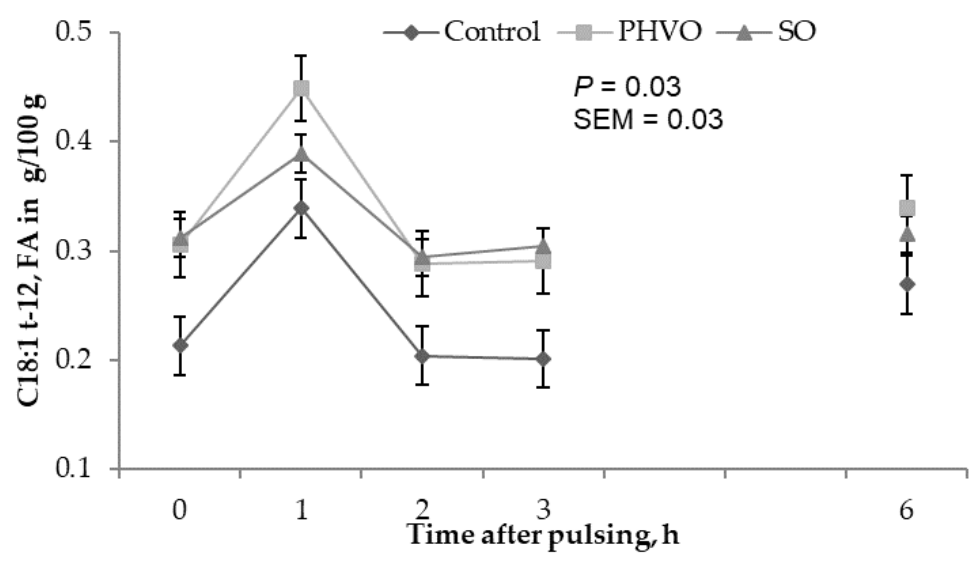

(C)

Figure 3. Time variations of C18:1 trans fatty acids in plasma from cows subjected to ruminal pulses of control, partially hydrogenated vegetable oil and soybean oil. (A) C18:1t-4; (B) C18:1t-5; and (C) C18:1t-12. Blood samples were collected prior to ruminal pulse (0 h;09:00) and 1, 2, 3 and $6 \mathrm{~h}$ after ruminal pulse. SEM = standard error of the mean. Means are pooled across days for each cow. $p$-value represents the effect of sampling time.

The relatively short treatment (single administration per day), and sampling ( $3 \mathrm{~d}$ ) periods in the current study were selected to provoke the extensive biohydrogenation effects on oil pulses that are often observed during the first few hours after administration [16]. The oil administration method can affect how long oil remains in the rumen. With a single administration of $250 \mathrm{~g} / \mathrm{d}$ of oil in $500 \mathrm{~mL} / \mathrm{d}$ of SM, plasma FA concentrations were higher during the first few hours after pulse and lower in subsequent hours. Generally, sampling day had a linear effect on C18:1 trans isomers in plasma, HDL and LDL. In the current study, effects of treatments on the TFA profile of plasma and lipoprotein fractions were observed within the first three hours post-pulse. Sampling day affected the TFA of plasma and lipoprotein fractions. Under on-farm conditions, ruminal metabolism of dietary lipids can be slower than with rumen pulses, and metabolism depends on feeding management (e.g., pasture-based diets vs. total mixed rations; varying forage to concentrate ratio) and production traits (e.g., body weight, milk yield and energy efficiency), among other variables.

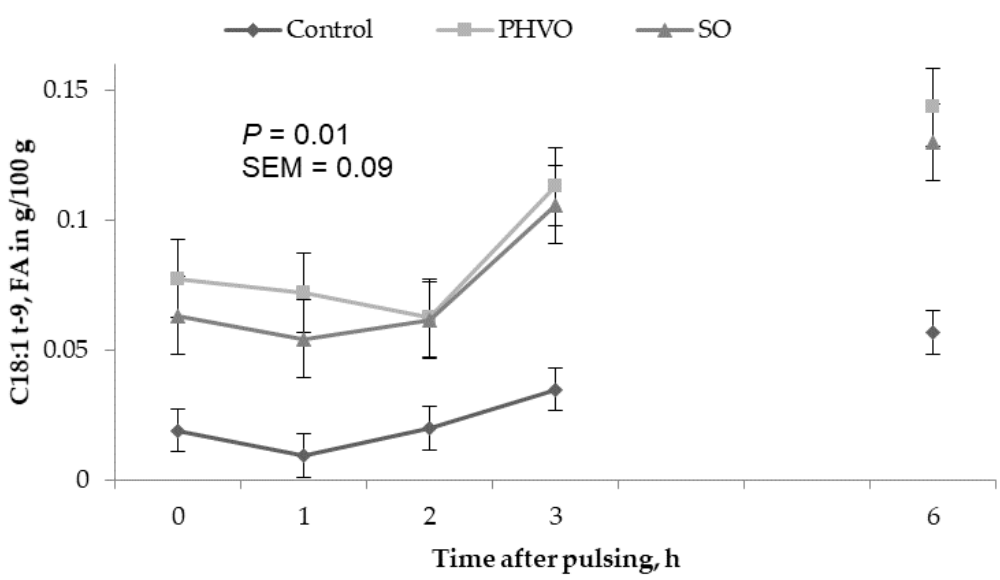

Figure 4. Time variations of C18:1t-9 in high density lipoprotein from cows subjected to ruminal pulses of control, partially hydrogenated vegetable oil and soybean oil. Blood samples were collected prior to ruminal pulse $(0 \mathrm{~h} ; 09: 00)$ and $1,2,3$ and $6 \mathrm{~h}$ after ruminal pulse. SEM = standard error of the mean. Means are pooled across days for each cow. $p$-value represents the effect of sampling time. 
The amount and composition of lipids circulating in the blood of dairy cattle are dependent upon a number of physiological variables; nature of the diet, time since feeding, age, breed, pregnancy and stage of lactation may all affect lipid content and composition [50]. In the current study, diurnal variations of plasma, lipoprotein fractions and ruminal fermentation parameters suggested there might be adaptation of ruminal microbiome to treatments [51]. Future studies should focus on the rumen microbiome and consider longer treatment periods to test this hypothesis.

Identification of key C18:1 trans isomers during the daily feeding cycle could be used to evaluate production of intermediates from different polyunsaturated oils with less risk of bias than in vitro trials [11]. In on-farm conditions, cows may be fed with different sources of polyunsaturated FA, such as oilseed by-products, that behave similarly to observations in the current study. Furthermore, cows might be fed with bypass fats that are usually made from hydrogenated vegetable oils [52]. Under the conditions of the current study, concentrations of C18:1 trans isomers appeared to be higher in the first $2 \mathrm{~h}$ post-rumen pulsing, then decreased after $2 \mathrm{~h}$ post-pulsing and finally increased steadily. The day and time responses observed in the current study were linked to the level of supplemented oil, the degree of accumulated unesterified FA, and rumen microbial adaptations [53]. In order to have a clear picture of the metabolic pathways for C18:1 trans isomers in the rumen, plasma, HDL and/or LDL, future work will need to consider long-term studies, lactating cows, rumen microbiome data, and milk FA profiles. Milk fats consist mainly of triglycerides (TAG; $98 \%$ ), and other types of lipids such as diacylglycerides ( $2 \%$ of the lipid fraction), cholesterol (less than $0.5 \%)$, polar lipids ( $1 \%$, mainly phospholipids) and free FA $(0.1 \%)$ [5]. Given that the mammary gland preferentially takes up FA from plasma TAG, it is recommended for future research to study FA accumulation of C18:1 TFA either as total plasma TAG or TAG concentrations in each lipoprotein fraction.

\subsection{Further Considerations}

The current study was designed to study short-term variations in plasma, lipoprotein fractions and ruminal fermentation parameters, which would be needed for mammary absorption studies in lactating cows. This study sheds light on the early-stage kinetics of plasma FA transport and rumen fermentation kinetics, which contributes to our understanding of long-term nutrition in dry cows that need to adapt to different metabolic challenges in the following early lactation phase. In this regard, our results showed that dietary lipids undergo extensive changes during the first hour post-pulse and in plasma and lipoproteins the majority of C18:1 TFA increased towards the third day after consecutive rumen pulses. Direct extrapolation of these results to lactating cows fed on total mixed rations is difficult as physiological state and energetic balance will differ, as will rates of FA influx and outflow from the rumen. However, differential effects of lipid sources on plasma FA were generally seen within one hour of pulsing, and most differences were maintained for $3 \mathrm{~h}$. This suggests that administration of different lipids in total mixed rations could lead to similar effects, but at lower magnitudes and more prolonged. Further research is required to test this suggestion.

Some additional factors need to be considered for interpretation of the present data. (1) Due to our methodological approach, it was not possible to separate the effect of time postfeeding and the effect of time post-administration of lipids (instead, control treatment could be used as a measure for this effect, or at least to identify effects of basal diet fermentation vs. oils). (2) The animals had ad libitum access to hay, but the commercial concentrate was offered at 12:00 ( $3 \mathrm{~h}$ after the pulse of lipids). Thus, the slight variations in fermentation parameters between 0 and $3 \mathrm{~h}$ (up to $3 \mathrm{~h}$ post-rumen pulsing) may be explained by hay intake, and the greater decrease in ruminal $\mathrm{pH}$ at $6 \mathrm{~h}$ post-rumen pulsing after the pulse of lipids would probably be attributable to concentrate intake. (3) Effects of sampling time on plasma fatty acid profiles may also be influenced by the feeding schedule. 


\section{Conclusions}

In summary, the results showed that there was an accumulation of several C18:1 TFA in plasma and lipoproteins, especially on the third day of rumen pulsing. Each C18:1 TFA responded differently to treatments over time. Our data show that naturally occurring C18:1 TFA isomers (produced during rumen biohydrogenation of $\mathrm{SO}$ ) and preformed TFA (supplied by PHVO) elicit differential FA partitioning and transport in plasma and lipoproteins.

Author Contributions: Conceptualization, E.V.-B.-P. and P.C.G.; methodology, E.V.-B.-P.; validation, E.V.-B.-P., J.J.L. and P.C.G.; formal analysis, E.V.-B.-P., J.J.L. and P.C.G.; investigation, E.V.-B.-P.; data curation, E.V.-B.-P.; writing - original draft preparation, E.V.-B.-P., P.C.G.; writing—review and editing, E.V.-B.-P., J.J.L. and P.C.G.; visualization, E.V.-B.-P.; supervision, P.C.G. All authors have read and agreed to the published version of the manuscript.

Funding: This research received no external funding.

Institutional Review Board Statement: All procedures were reviewed by the Animal Welfare and Ethical Review Board of the University of Nottingham and were conducted in accordance with the requirements of the UK Home Office Animals (Scientific Procedures) Act 1986 with a project license ID $40 / 2751$.

Informed Consent Statement: Not applicable.

Data Availability Statement: The data presented in this study are available on request from the corresponding author.

Acknowledgments: Einar Vargas-Bello-Pérez was supported by a postgraduate studentship (196739) from Consejo Nacional de Ciencia y Tecnología (CONACYT- México). We would like to thank Dongfang Li, Neil Saunders and Morag Hunter for technical assistance, and the staff of the University of Nottingham Biosciences Research Unit for care of the cows. Statistical advice was provided by Jim Craigon.

Conflicts of Interest: The authors declare no conflict of interest.

\section{References}

1. Piperova, L.S.; Moallem, U.; Teter, B.B.; Sampugna, J.; Yurawecz, M.P.; Morehouse, K.M.; Luchini, D.; Erdman, R.A. Changes in milk fat in response to dietary supplementation with calcium salts of trans-18:1 or conjugated linoleic fatty acids in lactating dairy cows. J. Dairy Sci. 2004, 87, 3836-3844. [CrossRef]

2. Meijer, G.W.; van Tol, A.; van Berkel, T.J.C.; Weststrate, J.A. Effect of dietary elaidic versus vaccenic acid on blood and liver lipids in the hamster. Atherosclerosis 2001, 157, 31-40. [CrossRef]

3. Kuhnt, K.; Baehr, M.; Rohrer, C.; Jahreis, G. Trans fatty acid isomers and the trans-9/trans-11 index in fat containing foods. Eur. J. Lipid. Sci. Technol. 2011, 113, 1281-1292. [CrossRef]

4. Oteng, A.-B.; Kersten, S. Mechanisms of Action of trans Fatty Acids. Adv. Nutr. 2020, 11, 697-708. [CrossRef] [PubMed]

5. Bernard, L.; Bonnet, M.; Delavaud, C.; Delosière, M.; Ferlay, A.; Fougère, H.; Graulet, B. Milk Fat Globule in Ruminant: Major and Minor Compounds, Nutritional Regulation and Differences Among Species. Eur. J. Lipid Sci. Technol. 2018, 120, 1700039. [CrossRef]

6. Vargas-Bello-Pérez, E.; Fehrmann-Cartes, K.; Íñiguez-González, G.; Toro-Mujica, P.; Garnsworthy, P.C. Short communication: Chemical composition, fatty acid composition, and sensory characteristics of Chanco cheese from dairy cows supplemented with soybean and hydrogenated vegetable oils. J. Dairy Sci. 2015, 98, 111-117. [CrossRef]

7. Lock, A.L.; Garnsworthy, P.C. Independent effects of dietary linoleic and linolenic fatty acids on the conjugated linoleic acid content of cows' milk. Anim. Sci. 2002, 74, 163-176. [CrossRef]

8. Ahmad, F.; Sun, Q.; Patel, D.; Stommel, J.M. Cholesterol metabolism: A potential therapeutic target in glioblastoma. Cancers 2019, 11, 146. [CrossRef] [PubMed]

9. Offer, N.W.; Speake, B.K.; Dixon, J.; Marsden, M. Effect of fish-oil supplementation on levels of (n-3) poly-unsaturated fatty acids in the lipoprotein fractions of bovine plasma. Anim. Sci. 2001, 73, 523-531. [CrossRef]

10. Sun, X.Q.; Gibbs, S.J. Diurnal variation in fatty acid profiles in rumen digesta from dairy cows grazing high-quality pasture. Anim. Feed Sci. Technol. 2012, 177, 152-160. [CrossRef]

11. Loor, J.J.; Ueda, K.; Ferlay, A.; Chilliard, Y.; Doreau, M. Short Communication: Diurnal Profiles of Conjugated Linoleic Acids and Trans Fatty Acids in Ruminal Fluid from Cows Fed a High Concentrate Diet Supplemented with Fish Oil, Linseed Oil, or Sunflower Oil. J. Dairy Sci. 2004, 87, 2468-2471. [CrossRef] 
12. Colman, E.; Tas, B.M.; Waegeman, W.; De Baets, B.; Fievez, V. The logistic curve as a tool to describe the daily ruminal pH pattern and its link with milk fatty acids. J. Dairy Sci. 2012, 95, 5845-5865. [CrossRef] [PubMed]

13. Vargas-Bello-Pérez, E.; Íñiguez-González, G.; Cancino-Padilla, N.; Loor, J.J.; Garnsworthy, P.C. Effect of dietary vegetable oils on the fatty acid profile of plasma lipoproteins in dairy cows. Arch. Anim. Nutr. 2016, 70, 322-332. [CrossRef]

14. Vargas-Bello-Pérez, E.; Íñiguez-González, G.; Garnsworthy, P.C.; Loor, J.J. Transport of fatty acids within plasma lipoproteins in lactating and non-lactating cows fed on fish oil and hydrogenated palm oil. J. Anim. Physiol. Anim. Nutr. 2017, 101, 369-377. [CrossRef] [PubMed]

15. Boudon, A.; Faverdin, P.; Delagarde, R.; Lamberton, P.; Peyraud, J.L. Effects of Rumen or Duodenal Glucose Infusions on Intake in Dairy Cows Fed Fresh Perennial Ryegrass Indoors. J. Dairy Sci. 2007, 90, 4397-4410. [CrossRef] [PubMed]

16. Doreau, M.; Batisse, V.; Bauchart, D. Apprrciation de l'hydrogrnation des acides gras alimentaires darts le rumen de la vache: 6tude mrthodologique preliminaire. Ann. Zootech. 1989, 38, 139-144. [CrossRef]

17. Vargas-Bello-Pérez, E.; Geldsetzer-Mendoza, C.; Morales, M.S.; Toro-Mujica, P.; Fellenberg, M.A.; Ibáñez, R.A.; Gómez-Cortés, P.; Garnsworthy, P.C. Effect of olive oil in dairy cow diets on the fatty acid profile and sensory characteristics of cheese. Int. Dairy J. 2018, 85, 8-15. [CrossRef]

18. Vargas-Bello-Pérez, E.; Cancino-Padilla, N.; Geldsetzer-Mendoza, C.; Vyhmeister, S.; Morales, M.S.; Leskinen, H.; Romero, J.; Garnsworthy, P.C.; Ibáñez, R.A. Effect of Feeding Cows with Unsaturated Fatty Acid Sources on Milk Production, Milk Composition, Milk Fatty Acid Profile, and Physicochemical and Sensory Characteristics of Ice Cream. Animals 2019, 9, 568. [CrossRef]

19. Contreras, G.A.; O’Boyle, N.J.; Herdt, T.H.; Sordillo, L.M. Lipomobilization in periparturient dairy cows influences the composition of plasma nonesterified fatty acids and leukocyte phospholipid fatty acids. J. Dairy Sci. 2010, 93, 2508-2516. [CrossRef]

20. Watts, J.S.; Rezamand, P.; Sevier, D.L.; Price, W.; McGuire, M.A. Short-term effects of dietary trans fatty acids compared with saturated fatty acids on selected measures of inflammation, fatty acid profiles, and production in early lactating Holstein dairy cows. J. Dairy Sci. 2013, 96, 6932-6943. [CrossRef]

21. Andersen, J.B.; Ridder, C.; Larsen, T. Priming the Cow for Mobilization in the Periparturient Period: Effects of Supplementing the Dry Cow with Saturated Fat or Linseed. J. Dairy Sci. 2008, 91, 1029-1043. [CrossRef]

22. Santschi, D.E.; Wettstein, H.-R.; Leiber, F.; Witschi, A.-K.M.; Kreuzer, M. Colostrum and milk fatty acids of dairy cows as influenced by extruded linseed supplementation during the transition period. Can. J. Anim. Sci. 2009, 89, 383-392. [CrossRef]

23. Leiber, F.; Hochstrasser, R.; Wettstein, H.R.; Kreuzer, M. Feeding transition cows with oilseeds: Effects on fatty acid composition of adipose tissue, colostrum and milk. Livest. Sci. 2011, 138, 1-12. [CrossRef]

24. Petit, H.V.; Benchaar, C. Milk production, milk composition, blood composition, and conception rate of transition dairy cows fed different profiles of fatty acids. Can. J. Anim. Sci. 2007, 87, 591-600. [CrossRef]

25. Badiei, A.; Aliverdilou, A.; Amanlou, H.; Beheshti, M.; Dirandeh, E.; Masoumi, R.; Moosakhani, F.; Petit, H.V. Postpartum responses of dairy cows supplemented with n-3 fatty acids for different durations during the peripartal period. J. Dairy Sci. 2014, 97, 6391-6399. [CrossRef] [PubMed]

26. Agriculture and Food Research Council. Energy and Protein Requirements of Ruminants. An Advisory Manual Prepared by the AFRC Technical Committee on Responses to Nutrients; CAB International: Wallingford, UK, 1993.

27. Ferlay, A.; Doreau, M. Influence of Method of Administration of Rapeseed Oil in Dairy Cows. 1. Digestion of Nonlipid Components. J. Dairy Sci. 1992, 75, 3020-3027. [CrossRef]

28. Radding, C.M.; Steinberg, D. Studies on the synthesis and secretion of serum lipoproteins by rat liver slices. J. Clin. Investig. 1960, 39, 1560-1569. [CrossRef]

29. Hara, A.; Radin, N.S. Lipid extraction of tissues with a low-toxicity solvent. Anal. Biochem. 1978, 90, 420-426. [CrossRef]

30. Chichlowski, M.W.; Schroeder, J.W.; Park, C.S.; Keller, W.L.; Schimek, D.E. Altering the fatty acids in milk fat by including canola seed in dairy cattle diets. J. Dairy Sci. 2005, 88, 3084-3094. [CrossRef]

31. Harvatine, K.J.; Allen, M.S. Effects of Fatty Acid Supplements on Ruminal and Total Tract Nutrient Digestion in Lactating Dairy Cows. J. Dairy Sci. 2006, 89, 1092-1103. [CrossRef]

32. Hristov, A.N.; Ropp, J.K. Effect of Dietary Carbohydrate Composition and Availability on Utilization of Ruminal Ammonia Nitrogen for Milk Protein Synthesis in Dairy Cows. J. Dairy Sci. 2003, 86, 2416-2427. [CrossRef]

33. Knothe, G.; Dunn, R.O. A Comprehensive Evaluation of the Melting Points of Fatty Acids and Esters Determined by Differential Scanning Calorimetry. J. Am. Oil Chem. Soc. 2009, 86, 843-856. [CrossRef]

34. Vargas-Bello-Pérez, E.; Cancino-Padilla, N.; Romero, J.; Garnsworthy, P.C. Quantitative analysis of ruminal bacterial populations involved in lipid metabolism in dairy cows fed different vegetable oils. Animal 2016, 10, 1821-1828. [CrossRef] [PubMed]

35. Yang, S.L.; Bu, D.P.; Wang, J.Q.; Hu, Z.Y.; Li, D.; Wei, H.Y.; Zhou, L.Y.; Loor, J.J. Soybean oil and linseed oil supplementation affect profiles of ruminal microorganisms in dairy cows. Animal 2009, 3, 1562-1569. [CrossRef]

36. Guyader, J.; Eugène, M.; Nozière, P.; Morgavi, D.P.; Doreau, M.; Martin, C. Influence of rumen protozoa on methane emission in ruminants: A meta-analysis approach. Animal 2014, 8, 1816-1825. [CrossRef] [PubMed]

37. Jordan, E.; Lovett, D.K.; Monahan, F.J.; Callan, J.; Flynn, B.; O'Mara, F.P. Effect of refined coconut oil or copra meal on methane output and on intake and performance of beef heifers. J. Anim. Sci. 2006, 84, 162-170. [CrossRef] [PubMed]

38. Hackmann, T.J.; Firkins, J.L. Maximizing efficiency of rumen microbial protein production. Front. Microbiol. 2015, 6. [CrossRef]

39. Gustafsson, A.H.; Palmquist, D.L. Diurnal variation of rumen ammonia, serum urea, and milk urea in dairy cows at high and low yields. J. Dairy Sci. 1993, 76, 475-484. [CrossRef] 
40. Roy, A.; Mandal, G.P.; Patra, A.K. Effects of different vegetable oils on rumen fermentation and conjugated linoleic acid concentration in vitro. Vet. World 2017, 10, 11-16. [CrossRef]

41. Bauman, D.E.; Mather, I.H.; Wall, R.J.; Lock, A.L. Major advances associated with the biosynthesis of milk. J. Dairy Sci. 2006, 89, 1235-1243. [CrossRef]

42. Bauman, D.E.; Harvatine, K.J.; Lock, A.L. Nutrigenomics, Rumen-Derived Bioactive Fatty Acids, and the Regulation of Milk Fat Synthesis. Annu. Rev. Nutr. 2011, 31, 299-319. [CrossRef]

43. Grażyna, C.; Hanna, C.; Adam, A.; Magdalena, B.M. Natural antioxidants in milk and dairy products. Int. J. Dairy Technol. 2017, 70, 165-178. [CrossRef]

44. Young, J.F.; Therkildsen, M.; Ekstrand, B.; Che, B.N.; Larsen, M.K.; Oksbjerg, N.; Stagsted, J. Novel aspects of health promoting compounds in meat. Meat Sci. 2013, 95, 904-911. [CrossRef] [PubMed]

45. Doreau, M.; Ferlay, A. Digestion and utilisation of fatty acids by ruminants. Anim. Feed Sci. Technol. 1994, 45, 379-396. [CrossRef]

46. Glasser, F.; Ferlay, A.; Doreau, M.; Schmidely, P.; Sauvant, D.; Chilliard, Y. Long-Chain Fatty Acid Metabolism in Dairy Cows: A Meta-Analysis of Milk Fatty Acid Yield in Relation to Duodenal Flows and De Novo Synthesis. J. Dairy Sci. 2008, 91, $2771-2785$. [CrossRef]

47. Arrigoni, M.D.B.; Martins, C.L.; Factori, M.A. Lipid metabolism in the rumen. In Rumenology; Springer: Berlin/Heidelberg, Germany, 2016; pp. 103-126.

48. Antongiovanni, M.; Buccioni, A.; Petacchi, F.; Secchiari, P.; Mele, M.; Serra, A. Upgrading the lipid fraction of foods of animal origin by dietary means: Rumen activity and presence of trans fatty acids and CLA in milk and meat. Ital. J. Anim. Sci. 2003, 2, 3-28. [CrossRef]

49. Jenkins, T.C. Lipid Metabolism in the Rumen. J. Dairy Sci. 1993, 76, 3851-3863. [CrossRef]

50. Christie, W.W. The composition, structure and function of lipids in the tissues of ruminant animals. In Lipid Metabolism in Ruminant Animals; Christie, Ed.; Pergamon Press: New York, NY, USA, 1981; p. 95.

51. Bitman, J.; Wood, D.L.; Lefcourt, A.M. Rhythms in Cholesterol, Cholesteryl Esters, Free Fatty Acids, and Triglycerides in Blood of Lactating Dairy Cows. J. Dairy Sci. 1990, 73, 948-955. [CrossRef]

52. Palmquist, D.L.; Jenkins, T.C. A 100-Year Review: Fat feeding of dairy cows. J. Dairy Sci. 2017, 100, 10061-10077. [CrossRef]

53. Kim, E.J.; Huws, S.A.; Lee, M.R.F.; Scollan, N.D. Dietary Transformation of Lipid in the Rumen Microbial Ecosystem. AsianAustralas. J. Anim. Sci. 2009, 22, 1341-1350. [CrossRef] 